\title{
Comparative Study of Different Thermospray Interfaces with Carbamate Pesticides: Influence of the Ion Source Geometry
}

\author{
Dietrich Volmer and Karsten Levsen \\ Department of Analytical Chemistry, Fraunhofer Institute for Toxicology and Aerosol Research, Hannover, \\ Germany
}

Maarten Honing and Damia Barceló

Department of Environmental Chemistry, CID/CSIC, Barcelona, Spain

Joaquín Abian and Emilio Gelpí

Department of Bioanalysis, CID/CSIC, Barcelona, Spain

Ben L. M. van Baar

Department of Organic Chemistry, Free University, Amsterdam, The Netherlands

\author{
Udo A. Th. Brinkman \\ Department of Analytical Chemistry, Free University, Amsterdam, The Netherlands
}

\begin{abstract}
Sixteen carbamate pesticides that belong to four chemical classes (oxime- $N$-methylcarbamates, aryl $N$-methylcarbamates, $N$-phenylcarbamates, and methyl esters of substituted carbamic acids) were investigated via three different commercially available thermospray interfaces and ion sources that exhibit wide differences in source geometry. Comparisons were made between the three interfaces with respect to ion formation and sensitivity of detection. Experimental parameters were standardized to obtain comparable experimental conditions. Very similar mass spectra for most carbamates were obtained that illustrate independence from the geometry of the ionization and desolvation chambers of the interfaces. These findings are in sharp contrast to several literature reports. However, thermally labile carbamates gave unsatisfactory results with regard to spectral compatibility between the interfaces. Such differences were due to thermally assisted hydrolysis reactions that occur in the vaporizer probe prior to ionization and reflect differences in the vaporizer designs. The study proves conclusively that comparable spectra can be obtained under thermospray with different interfaces and mass spectrometers. (J Am Soc Mass Spectrom 1995, 6, 656-667)
\end{abstract}

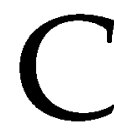
urrently thermospray (TSP) has been used extensively as a liquid chromatography-mass spectrometry (LC-MS) interface for the determination of a wide range of chemical classes; for example, pesticides [1-7], azo dyes [8], drugs [9], and toxins $[10,11]$. Interlaboratory validations have shown that this interface can be used for the quantification of a variety of pesticides [12, 13]. Many experimental parameters, however, such as repeller voltage $[14,15]$, interface temperature $[1,5]$, and the composition of the

Address reprint requests to Maarten Honing, Department of Environmental Chemistry, CID/CSIC, Jordi Girona 18-26, 08034, Barcelona Spain or Dr. Dietrich Volmer, U.S. Food and Drug Administration, National Center for Toxicological Research, 3900 NCTR Road, Jefferson, AR 72079. mobile phase $[16,17]$, require adjustments to obtain the necessary limits of detection and reproducibility.

Mass spectrometric investigations of carbamate pesticides via different types of TSP interfaces have been reported widely $[1-7,18-26]$. These studies, however, indicate that solitary protonated molecules and/or molecular ammonium adduct ions are formed by carbamates that provide no structural information. For an unambiguous identification of carbamates in environmental samples, several additional fragment ions are required for proof of presence. Several methods have been reported to increase the number of fragment ions; for example, use of different ionization modes $[1,6]$, postcolumn addition of adduct reagents [4, 19] or increased operating temperatures of the TSP interface 
to enhance thermal fragmentation [5]. An increase of either the ion source or vaporizer temperature typically causes the dissociation of adduct ions, such as molecular ammonium adduct ions $\left[\mathrm{M}+\mathrm{H}+\mathrm{NH}_{3}\right]^{+}$, and often the formation of fragment ions; for example, $\left[\mathrm{M}+\mathrm{H}-\mathrm{CH}_{3} \mathrm{NCO}\right]^{+}$or $[\mathrm{M}+\mathrm{H}-$ $\left.\mathrm{CH}_{3} \mathrm{NHCOOH}\right]^{+}$from $\mathrm{N}$-methylcarbamates [1].

Adduct ions such as $[\mathrm{M}+32]^{+}$and $[\mathrm{M}+59]^{+}$ sometimes are observed with carbamates $[1,5,18]$. The $[\mathrm{M}+59]^{+}$adduct ion has been shown to be due to an impurity in the commercially available ammonium acetate [27]. Formation of the $[\mathrm{M}+32]^{+}$ion has been explained by means of unique ion-molecule reactions in the gas phase [18].

TSP mass spectra reported in the literature are, however, inconsistent. For example, the relative abundances of protonated molecules, molecular ammonium adduct ions, and fragment ions for carbofuran for different TSP systems and source temperatures (but comparable vaporizer temperature and mobile phases) are listed in Table 1. Ion abundances are inconsistent for different TSP systems (but identical ion source temperatures) and also for identical systems by application of different source temperatures. The latter effect might be explained in part by thermal dissociations. Differences in the TSP mass spectra obtained with different types of interfaces can be because of differences in source geometry and the ion source pressure. Although this statement generally has been used to explain differences in various experimental results, the influence of the ion source geometry on the ion formation of carbamates in thermospray mass spectrometry has not yet been investigated fully.

The purpose of this study was to investigate the direct influence of the ion source geometry on ion formation. Experimental parameters, such as interface temperatures, mobile phase composition, and flow rate, were maintained at constant values. Target compounds for this study were 16 carbamate pesticides (6 oxime $N$-methylcarbamates, 6 aryl $N$-methylcarbamates, $2 \mathrm{~N}$-phenylcarbamates, and 2 methyl esters from substituted carbamic acids). Three commercially available thermospray systems, which exhibit substantial differences in vaporizer, desolvation, and ionization chamber design, were used to study and compare the influence of the source geometry.

\section{Experimental}

\section{Chemicals}

All pesticides (purity $>98 \%$ ) were obtained from Riedel-de Haën (Seelze-Hannover, Germany) and Promochem (Wesel, Germany) and were used without further purification. Methanol (Merck, Darmstadt, Germany) and organic-free water (Millipore, Bedford, MA) were used as solvents. Ammonium acetate and ammonium hydroxide (25\% solution) were purchased from Merck. Acetic acid was purchased from both Sharlau (Barcelona, Spain) and Merck.

\section{Solutions}

Stock solutions of the 16 carbamates at a concentration level of approximately $100 \mathrm{mg} / \mathrm{l}$ were prepared in methanol and stored in the dark at $-20^{\circ} \mathrm{C}$. Standard solutions were diluted twice with water before use. An ammonium acetate buffer ( $\mathrm{pH}$ 5.0) was prepared by adding $0.1 \mathrm{~mol}$ of acetic acid to $0.5 \mathrm{~L}$ of water, followed by dilution with $0.1 \mathrm{~mol}$ of ammonium hydroxide and water to $1 \mathrm{~L}$ final volume. This $200-\mathrm{mM}$ solution was adjusted to $\mathrm{pH} 5.0$ with acetic acid. Finally, this solution was mixed with $1 \mathrm{~L}$ of methanol.

\section{Thermospray}

The thermospray mass spectra were obtained via three commercial TSP systems: System A, Vestec 701 (Houston, TX); System B, HP 5988A (Hewlett Packard, Palo Alto, CA); System C, Finnigan TSP 2 (Finnigan MAT, Bremen, Germany). Representations of the three ion sources are illustrated in Figure 1. The ion source of System $C$ is a cylindrical tube with an equal diameter thoughout the entire source, whereas both other systems have a narrowing of the source near the sampling cone. System A still has a desolvation chamber with a constant diameter, but the volume of the ionization chamber is reduced by the large repeller electrode and the exit cone. The decrease of source volume is even

Table 1. Main ions and their relative abundances in the thermospray mass spectra of carbofuran reported in the literature

\begin{tabular}{llclr}
\hline Interface $^{\mathrm{a}}$ & \multicolumn{1}{c}{ Mode } & Source temp $\left({ }^{\circ} \mathrm{C}\right)$ & \multicolumn{1}{c}{$m / z$ (rel. ab., \%) } & Ref. \\
\hline \hline System I & Filament off & $182-190$ & 239(100), 222(67) & 26 \\
System II & Filament on & 250 & $222(100), 239(56), 253(13), 280(19)$ & 18 \\
System III & Filament off & 200 & $222(100), 239^{\text {b }}$ & 25 \\
System IV & Filament off & 250 & $222(100), 239(35), 165(5), 182(3)$ & 5 \\
System V & Filament on & 270 & $239(100), 222(40), 280(10)$ & 24 \\
System V & Filament on & 240 & $222(100), 239(40)$ & 23 \\
System V & Filament on & 200 & $222(100), 239(40)$ & 1 \\
\hline
\end{tabular}

\footnotetext{
a For the make of the various interfaces, refer to the original articles.
}

belative abundance not reported. 


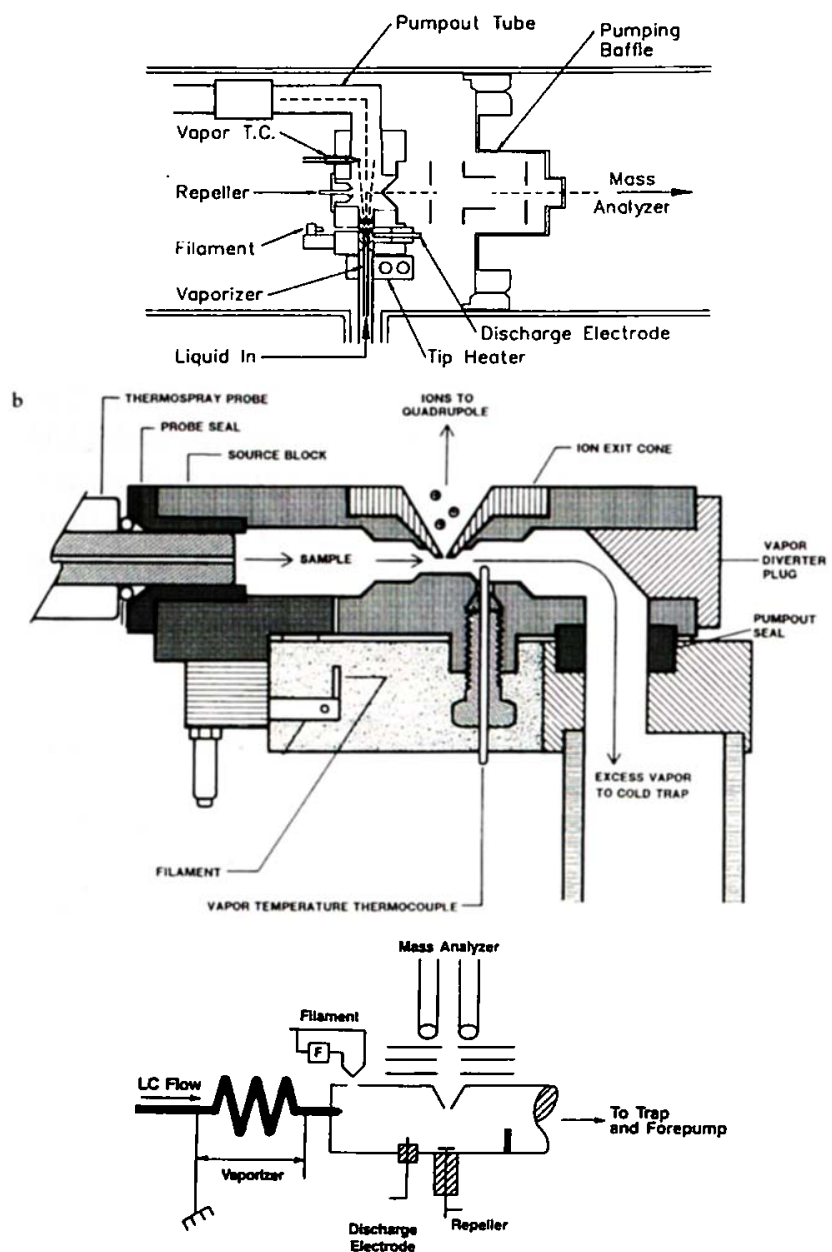

Figure 1. Schematic representation of the three investigated thermospray systems.

more important in System B: The diameter decreases along the passage from the desolvation chamber to the ionization chamber (Figure 1).

Rheodyne (Cotati, CA) 7125 injectors equipped with $10-\mu \mathrm{L}$ loops were used to introduce the sample solutions in the mobile phase [methanol:water $=50: 50$ $(\mathrm{v} / \mathrm{v})$ either with or without ammonium acetate at a concentration of $50 \mathrm{mM}$; flow rate $=1.0 \mathrm{~mL} / \mathrm{min}]$. All experiments were performed by using filamentassisted buffer ionization with ammonium acetate, direct thermospray ionization with ammonium acetate (filament off), and solvent-mediated chemical ionization (CI) without ammonium acetate (filament on). Shimadzu (Duisburg, Germany) LC-9A, HP 1090 series 1 [Hewlett-Packard (HP), Waldbronn, Germany], and Applied Biosystems (Foster City, CA) model 140-A high performance liquid chromatography systems were used as solvent delivery devices for Systems A, B, and $C$, respectively.

With System A (Vestec) and B (HP) a tip temperature corresponding to $95 \%$ evaporation of the mobile phase was used. Because this point could not be deter- mined with System C (Finnigan), a temperature of $4^{\circ} \mathrm{C}$ below the temperature that corresponds to the maximum ion current was used. In summary, System A has a vaporizer temperature of $\sim 198^{\circ} \mathrm{C}$ and a vaporizer tip temperature of $270^{\circ} \mathrm{C}$; System B has a stem temperature of $92^{\circ} \mathrm{C}$ and a tip temperature of $\sim 202^{\circ} \mathrm{C}$; System $\mathrm{C}$ has a vaporizer temperature of $104^{\circ} \mathrm{C}$. Experiments were performed at ion source temperatures of 200,250 , and $300^{\circ} \mathrm{C}$ with all interfaces.

To closely approximate chromatographically separated peaks and to improve analytical precision, additional peak broadening was produced by insertion, between injector and interface of either a coiled stainless steel tube of approximately $50-\mathrm{cm}$ length or a $2-\mathrm{cm}$ precolumn packed with $5-\mu \mathrm{m}$ particles coated with a base-deactivated reversed-phase $C_{8}$ phase.

\section{Liquid Chromatography}

Liquid chromatographic separations were performed with a $12.5-\mathrm{cm} \times 3.0-\mathrm{mm}$ Merck column packed with Lichrospher $60 \mathrm{RP}$-select-B $(5 \mu \mathrm{m})$. A flow rate of 0.6 $\mathrm{mL} / \mathrm{min}$, supplied by a HP 1090 series 1 gradient pump, with a linear gradient from 20 to $95 \%$ methanol in water during $45 \mathrm{~min}$, was used. A $175-\mathrm{mM}$ ammonium acetate solution in water was added postcolumn with a Knauer (Bad Homburg, Germany) model 64 pump, with a flow rate of $0.4 \mathrm{~mL} / \mathrm{min}$, which resulted in a total flow rate of $1.0 \mathrm{~mL} / \mathrm{min}$ and a final ammonium acetate concentration of $70 \mathrm{mM}$ in the mobile phase $[4,6,7]$.

\section{Carbamate Pesticides Used as Target Compounds}

Carbamate pesticides that belong to four different chemical classes of carbamates were used: (1) oxime $\mathrm{N}$-methylcarbamates, (2) aryl $\mathrm{N}$-methylcarbamates, (3) $\mathrm{N}$-phenylcarbamates, and (4) methyl esters of substituted carbamic acids. Table 2 lists the commercial name, CAS number, chemical class, nominal mass, and structure of the individual carbamates. These 16 carbamates span the most important members of the carbamate pesticide group.

\section{Signal-to-Noise Ratios}

Investigation of the influence of the ion source temperature on the signal-to-noise $(\mathrm{S} / \mathrm{N})$ ratios was performed on three carbamates - methomyl, promecarb, and thiodicarb.

Flow injections of $2 \mathrm{ng}$ of each compound by using the selected ion monitoring mode at ion source temperatures of $200,220,240,260,280$, and $300^{\circ} \mathrm{C}$ were conducted. For each temperature, multiple (five) injections for every compound were conducted. Prior to this experiment, all systems were tuned by using the protonated molecule ions of these compounds at $\mathrm{m} / \mathrm{z}$ 163,208 , and 355 with the ammonium acetate buffer solution that contained $2 \mathrm{ppm}$ of the three carbamates. 
Table 2. General information of the carbamate pesticides and some of their degradation products

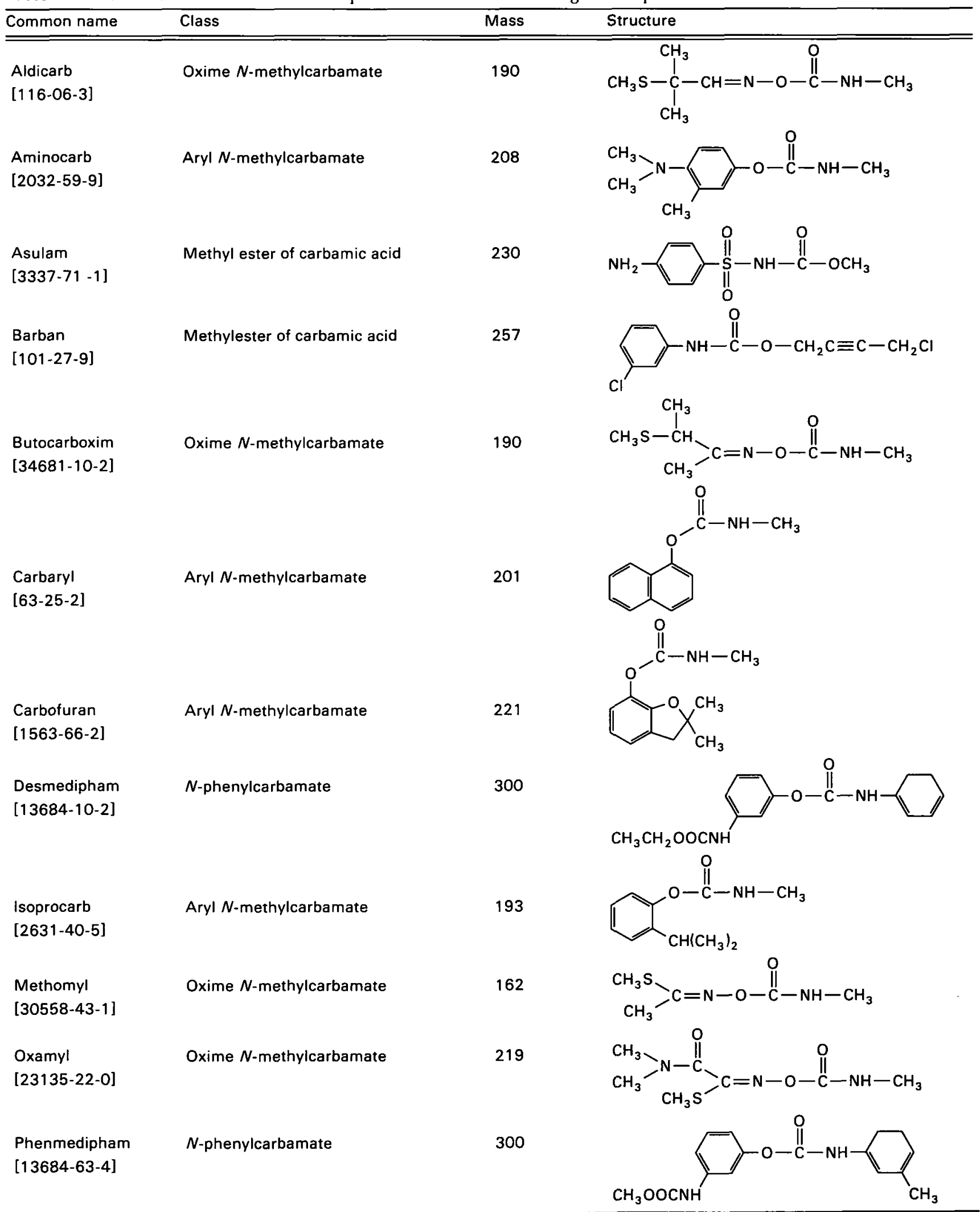


Table 2. General information of the carbamate pesticides and some of their degradation products (continued)

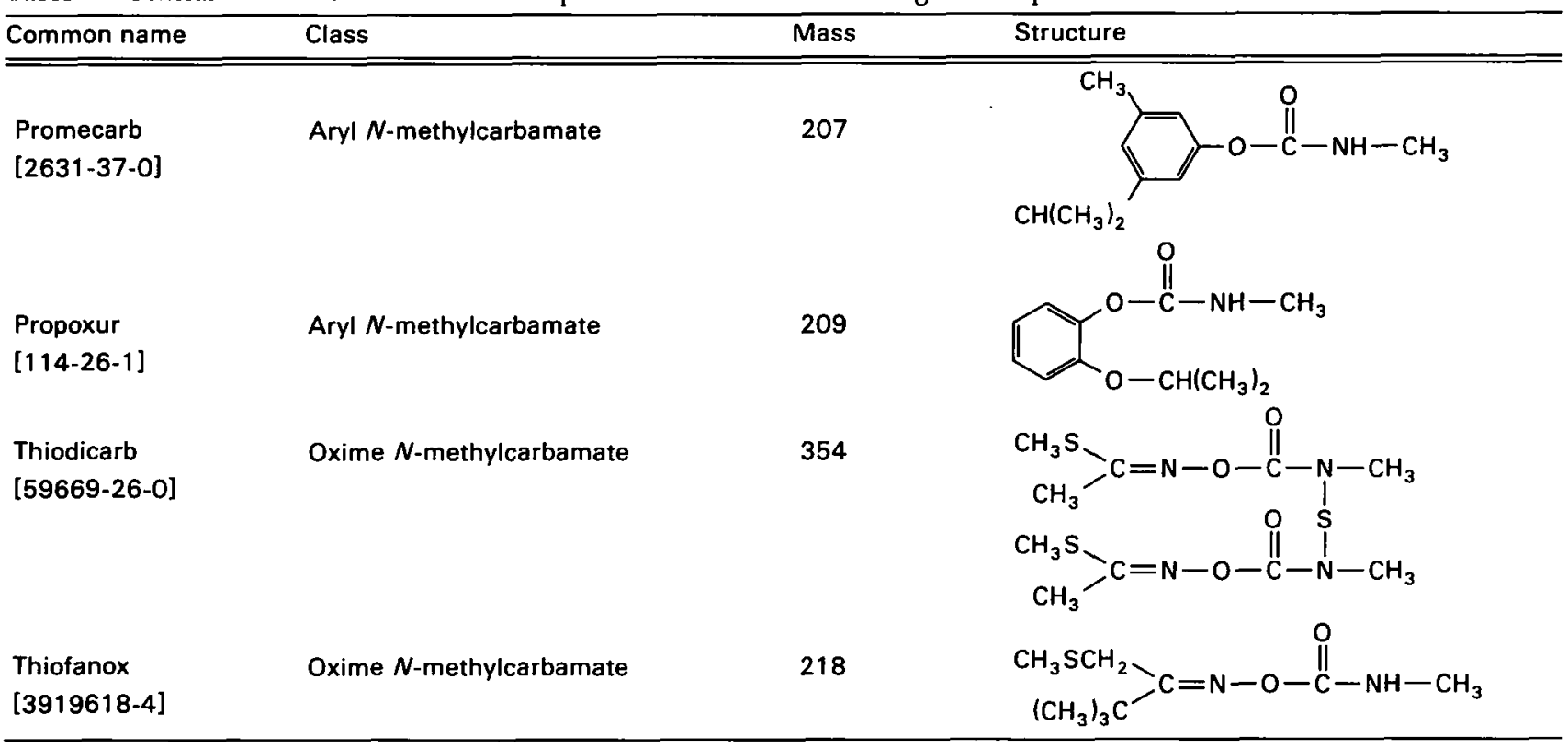

\section{Results and Discussion}

The different designs of the three TSP ion sources already have been discussed in the Experimental section (see also Figure 1). All experiments were performed at ion source temperatures of 200, 250, and $300^{\circ} \mathrm{C}$ via either direct thermospray, filament-assisted buffer ionization, or solvent-mediated chemical ionization. The spectra derived from the first two ionization modes were very similar. Consequently, to minimize the amount of data, only the results for the filamentassisted buffer ionization and solvent-mediated $\mathrm{CI}$ experiments will be discussed in this report (further data are available from the corresponding author upon request). Corresponding experiments in the dischargeassisted buffer ionization mode were not performed, because System B was not equipped with a discharge electrode. Table 3 summarizes the mass spectra obtained for the 16 target carbamates for Systems A, B, and $C$. (The results for solvent-mediated CI will be discussed only for some characteristic mass spectra; see subsequent text). Although the major discussion will be focused on the influence of the temperature and the ion source geometry on ion formation, a possible influence of the geometry of triple-stage quadrupole systems on ammonia cluster ions also is briefly discussed.

\section{Metastable Loss of Ammonia}

Metastable loss of ammonia by dissociative processes from ammonia cluster ions $\left[\mathrm{M}+\mathrm{H}+\mathrm{NH}_{3}\right]^{+}$occurs in triple-stage quadrupole mass spectrometers in the region between the first and third quadrupole as previously reported [27]. Obviously, the metastable loss of ammonia can generate differences in the mass spectra when the third quadrupole (Q3) is used as the scan- ning device instead of the first quadrupole (Q1). Thus, it was of importance to investigate this effect with the triple-stage quadrupole System $\mathrm{C}$ before initiation of the comparison with the single-stage quadrupole systems $\mathrm{A}$ and $\mathrm{B}$.

Five carbamates (aldicarb, carbofuran, thiodicarb, dioxacarb, and promecarb) were selected for this portion of the research. Experimental results are summarized in Table 4 for promecarb. At all source temperatures $\left(200,250\right.$, and $\left.300^{\circ} \mathrm{C}\right)$ aldicarb, dioxacarb, and promecarb exhibited ratios of total ion current of the protonated molecule ion relative to the molecular ammonium adduct ion, $[\mathrm{M}+\mathrm{H}]^{+} /\left[\mathrm{M}+\mathrm{H}+\mathrm{NH}_{3}\right]^{+}$, that were larger when $\mathrm{Q} 3$ rather than when $\mathrm{Q} 1$ was the scanning device (Table 4). These data are consistent with the metastable loss of ammonia from the $[\mathrm{M}+\mathrm{H}$ $\left.+\mathrm{NH}_{3}\right]^{+}$ion. The mass spectra of carbofuran and thiodicarb contained low abundant molecular ammonium adduct ions and thus no significant differences in the mass spectra between $\mathrm{Q} 1$ and $\mathrm{Q} 3$ were observed. The metastable loss of ammonia was less intense at higher source temperatures, because severe loss of ammonia had already taken place in the ion source. The fragmentation was only slightly affected by the triple-stage design; that is, no significant increase of the specific fragment ion $\left[\mathrm{M}+\mathrm{H}-\mathrm{CH}_{3} \mathrm{NCO}\right]^{+}$is observed when $\mathrm{Q} 3$ is used for mass scanning in comparison to Q1.

In conclusion, for the comparative study, Q1 was used for mass scanning with System $C$ rather than $Q 3$ to avoid metastable loss of ammonia as demonstrated in the foregoing text.

\section{Ion Formation: Filament-Assisted Buffer Ionization}

Filament-assisted buffer ionization mass spectra obtained with the three interfaces for the various carba- 
mates are discussed according to the chemical class of the target compounds.

Oxime $N$-methylcarbamates. For the oxime $N$-methylcarbamates (aldicarb, butocarboxim, methomyl, oxamyl, thiodicarb, and thiofanox), the mass spectra obtained with the three interfaces at an ion source temperature of $200^{\circ} \mathrm{C}$ are consistent (Table 3). Slight deviations were observed for methomyl at $200^{\circ} \mathrm{C}$; the ratio of the relative abundances of the protonated molecule ion and the molecular ammonium adduct ions was not consistent between the three interfaces. The source with the larger ionization chamber (System C) generated spectra for methomyl with less extensive molecular ammonium adduct ion formation as compared to the other systems with smaller ionization chambers. The same observations held for fragment ions. Thermally labile compounds such as thiodicarb exhibited a base peak at $m / z 180$ at $200^{\circ} \mathrm{C}$, which is the ammonium adduct ion of a fragment. For System $C$ the corresponding ion at $m / z 163$ is most abundant in the spectra. In the case of thiofanox, strong fragmentation was observed, especially with System C. In general, System C exhibited more fragmentation with thermally labile compounds. Degradation reactions are due to condensed-phase dissociations in the vaporizer probe prior to ionization. The design of the vaporizer of System C causes more thermal stress to the analytes than the other systems.

Aldicarb only exhibited the loss of $\mathrm{CH}_{3} \mathrm{NHCOOH}$, whereas for its isomers (butocarboxim and methomyl), loss of methylisocyanate $\left(\mathrm{CH}_{3} \mathrm{NCO}\right)$ was the preferred fragmentation pathway. This behavior is consistent with previously reported results [25]. Moreover, butocarboxim showed less abundant fragmentation than aldicarb. Oxamyl and thiofanox take an intermediate pathway and consequently their mass spectra contained both types of fragment ions. Competition between these two fragmentation pathways was influenced directly by the substituent at C-1 (Scheme I). This group can hamper a rearrangement reaction of the molecule after loss of the carbamic acid group similar to a condensed-phase Beckmann rearrangement that leads to the $[\mathrm{MH}-75]^{+}$ion. The methyl group (butocarboxim, methomyl) at C-1 appears to influence the loss of methylisocyanate. The presence of a proton (aldicarb), a tertiary butyl, or a carbonyl group leads to an ambident character.

N-Phenylcarbamates. The mass spectra of the thermally labile $N$-phenylcarbamates desmedipham and phenmedipham [5] were consistent with all interfaces at $200^{\circ} \mathrm{C}$. These compounds tend to form methanol and ammonia cluster ions of both the isocyanate and the alcohol moiety at low temperatures after thermally assisted degradation in the vaporizer. For phenmedipham the base peak is the ammonium adduct ion of the phenyl alcohol, which is formed after loss of
$\mathrm{CH}_{3} \mathrm{C}_{6} \mathrm{H}_{4} \mathrm{NCO}$ by thermally assisted hydrolysis in the vaporizer. Consequently, the neutral isocyanate also can give rise to ions, which are formed either by chemical reaction with solvent molecules and subsequent adduct formation with $\mathrm{NH}_{4}^{+}$or by direct ionization via $\mathrm{NH}_{4}^{+}$addition [4]. Again, more fragmentation is observed with System C than with both other systems because of the different vaporizer designs (see the subsequent discussion of the $[M+32]^{+}$ion).

Aryl-N-methylcarbamates. The mass spectra of the aryl- $N$-methylcarbamates were rather straightforward: they contained the molecular ammonium adduct ion; $\left[\mathrm{M}+\mathrm{H}+\mathrm{NH}_{3}\right]^{+}$and the protonated molecule ion $[\mathrm{M}+\mathrm{H}]^{+}$as major ions. For aminocarb, carbaryl, isoprocarb, and promecarb, good agreement of the mass spectra at an ion source temperature of $200^{\circ} \mathrm{C}$ from the different interfaces was obtained. Differences between the interfaces were observed in the relative abundances of the $\left[\mathrm{M}+\mathrm{H}+\mathrm{NH}_{3}\right]^{+}$and $[\mathrm{M}+\mathrm{H}]^{+}$ions for carbofuran and propoxur at all temperatures investigated. These results for carbofuran are, however, in agreement with previously published data (see Table 1). As for methomyl, the distinct design of the interfaces features differences in the mass spectra of carbofuran and propoxur. These differences are encountered mainly in changes of the relative abundances of the molecular ammonium adduct ions and the protonated molecule ions with temperature. The larger ionization chamber (System C) again favors the formation of the protonated molecule ions rather than the molecular ammonium adduct ions.

Carbamic acid esters. For barban, the mass spectra at $200^{\circ} \mathrm{C}$ were similar for the various interfaces. For this compound the molecular ammonium adduct ion was dominant. The protonated molecule ion $[\mathrm{M}+\mathrm{H}]^{+}$ $(m / z 258)$ and the ion at $m / z 239$, which was formed by loss of $\mathrm{HCl}$ from the $\left[\mathrm{M}+\mathrm{H}+\mathrm{NH}_{3}\right]^{+}$ion, are present in relative abundances $<10 \%$. For asulam, the fragment ion at $m / z 190$ was the base peak at all temperatures for all three interfaces. This ion was due to a degradation prior to ionization followed by ammonium addition as previously reported [5]. The abundance of the $\left[\mathrm{M}+\mathrm{H}+\mathrm{NH}_{3}\right]^{+}$ions at $m / z 248$ was found to be strongly dependent on the type of interface used; it was more abundant in the mass spectra of System A. Such differences appear to be influenced mainly by differences in the vaporizer temperatures applied with the three interfaces (see the following discussion of the $[M+32]^{+}$ion). Higher ion source temperatures result in a better similarity of the mass spectra.

In general, the abundances of molecular ammonium adduct ions for all compounds were the lowest in case of System C, whereas the abundance of fragment ions was most intensive with this interface. The decrease in the internal diameter of the desolvation chambers for 
Table 3. Main ions ( $m / z$ and relative abundances) and mass assignment of the investigated carbamates by filament-assisted buffer ionization. Comparison of three commercial TSP systems (A, B, and C) at source temperatures 200, 250, and $\left.300^{\circ} \mathrm{C}\right)^{\mathrm{a}}$

\begin{tabular}{|c|c|c|c|c|c|c|c|c|c|c|}
\hline \multirow[b]{2}{*}{$m / z$} & \multirow[b]{2}{*}{ Structure } & \multicolumn{3}{|c|}{$200^{\circ} \mathrm{C}$} & \multicolumn{3}{|c|}{$250^{\circ} \mathrm{C}$} & \multicolumn{3}{|c|}{$300^{\circ} \mathrm{C}$} \\
\hline & & A & $B$ & $\mathrm{C}$ & A & $B$ & $C$ & $A$ & $B$ & $\mathrm{C}$ \\
\hline \multicolumn{11}{|l|}{ Aldicarb } \\
\hline 249 & {$[M+59]^{+}$} & 3 & 8 & 10 & 2 & 11 & 14 & 1 & 7 & 16 \\
\hline 222 & {$[M+32]^{+}$} & 23 & 13 & 2 & 20 & 13 & 5 & 21 & 29 & 17 \\
\hline 208 & {$\left[\mathrm{M}+\mathrm{H}+\mathrm{NH}_{3}\right]^{+}$} & 100 & 100 & 100 & 100 & 100 & 100 & 100 & 100 & 45 \\
\hline 191 & {$[\mathrm{M}+\mathrm{H}]^{+}$} & 7 & 7 & 5 & 8 & 12 & 14 & 10 & 15 & 15 \\
\hline 148 & {$\left[\mathrm{M}+\mathrm{H}-\mathrm{MeNHCO}_{2} \mathrm{H}+\mathrm{MeOH}\right]^{+}$} & 7 & 6 & 15 & 14 & 24 & 59 & 30 & 60 & 100 \\
\hline \multicolumn{11}{|c|}{ Aminocarb } \\
\hline 267 & {$[M+59]^{+}$} & 2 & 6 & 4 & 1 & 8 & 3 & 1 & 2 & 1 \\
\hline 209 & {$[\mathrm{M}+\mathrm{H}]^{+}$} & 100 & 100 & 100 & 100 & 100 & 100 & 100 & 100 & 100 \\
\hline 152 & {$\left[\mathrm{M}+\mathrm{H}-\mathrm{CH}_{3} \mathrm{NCO}\right]^{+}$} & 7 & 3 & 4 & 22 & 5 & 5 & 31 & 10 & 9 \\
\hline \multicolumn{11}{|l|}{ Asulam } \\
\hline 248 & {$\left[\mathrm{M}+\mathrm{H}+\mathrm{NH}_{3}\right]^{+}$} & 100 & 12 & 5 & 18 & 5 & 8 & 40 & - & 7 \\
\hline 231 & {$[\mathrm{M}+\mathrm{H}]^{+}$} & 4 & 11 & 6 & 1 & 8 & 4 & 2 & - & 2 \\
\hline 222 & $?$ & - & 10 & - & 5 & 7 & - & 5 & - & - \\
\hline 190 & $\begin{array}{l}{\left[\mathrm{M}-\mathrm{CH}_{3} \mathrm{OCO}_{2} \mathrm{H}\right.} \\
\left.+\mathrm{H}_{2} \mathrm{O}+\mathrm{NH}_{4}\right]^{+}\end{array}$ & 77 & 100 & 100 & 100 & 100 & 100 & 100 & 100 & 100 \\
\hline 173 & $\begin{array}{l}{\left[\mathrm{M}-\mathrm{CH}_{3} \mathrm{OCO}_{2} \mathrm{H}\right.} \\
\left.+\mathrm{H}_{2} \mathrm{O}+\mathrm{H}\right]^{+}\end{array}$ & 1 & 1 & 1 & 3 & 4 & 4 & 4 & 9 & 10 \\
\hline \multicolumn{11}{|l|}{ Barban } \\
\hline 275 & {$\left[\mathrm{M}+\mathrm{H}+\mathrm{NH}_{3}\right]^{+}$} & 100 & 100 & 100 & 100 & 100 & 100 & 100 & 100 & 100 \\
\hline 258 & {$[\mathrm{M}+\mathrm{H}]^{+}$} & 1 & 1 & 1 & 3 & - & 5 & 5 & - & 8 \\
\hline 239 & {$\left[\mathrm{M}+\mathrm{H}+\mathrm{NH}_{3}-\mathrm{HCl}^{+}\right.$} & 1 & 1 & 3 & 6 & 8 & 4 & 4 & 16 & - \\
\hline 222 & {$[\mathrm{M}+\mathrm{H}-\mathrm{HCL}]^{+}$} & - & - & - & 8 & - & 2 & 5 & - & - \\
\hline \multicolumn{11}{|c|}{ Butocarboxim } \\
\hline 249 & {$[M+59]^{+}$} & 5 & 8 & 29 & 4 & 10 & 100 & 2 & 35 & na \\
\hline 222 & {$[M+32]^{+}$} & 23 & 6 & 3 & 60 & 6 & 14 & 72 & 29 & na \\
\hline 208 & {$\left[\mathrm{M}+\mathrm{H}+\mathrm{NH}_{3}\right]^{+}$} & 100 & 100 & 100 & 100 & 100 & 61 & 100 & 100 & na \\
\hline 191 & {$[\mathrm{M}+\mathrm{H}]^{+}$} & 22 & 14 & 3 & 38 & 31 & 30 & 44 & 79 & na \\
\hline \multicolumn{11}{|l|}{ Carbaryl } \\
\hline 260 & {$[M+59]^{+}$} & 2 & 8 & 7 & - & 5 & 6 & 1 & 1 & 7 \\
\hline 219 & {$\left[\mathrm{M}+\mathrm{H}+\mathrm{NH}_{3}\right]^{+}$} & 100 & 100 & 100 & 100 & 100 & 100 & 100 & 100 & 100 \\
\hline 202 & {$[\mathrm{M}+\mathrm{H}]^{+}$} & 9 & 6 & 4 & 10 & 9 & 19 & 10 & 21 & 99 \\
\hline 145 & {$\left[\mathrm{M}+\mathrm{H}-\mathrm{CH}_{3} \mathrm{NCO}^{+}\right.$} & - & - & - & 1 & - & 1 & 1 & - & 10 \\
\hline \multicolumn{11}{|c|}{ Carbofuran } \\
\hline 280 & {$[M+59]^{+}$} & 3 & 11 & 9 & 2 & 10 & 4 & 1 & 3 & 2 \\
\hline 239 & {$\left[\mathrm{M}+\mathrm{H}+\mathrm{NH}_{3}\right]^{+}$} & 100 & 100 & 26 & 63 & 71 & 5 & 30 & 10 & - \\
\hline 222 & {$[\mathrm{M}+\mathrm{H}]^{+}$} & 72 & 30 & 100 & 100 & 100 & 100 & 100 & 100 & 100 \\
\hline 182 & {$\left[\mathrm{M}+\mathrm{H}+\mathrm{NH}_{3}-\mathrm{CH}_{3} \mathrm{NCO}^{+}\right.$} & - & - & - & 4 & - & - & 5 & - & - \\
\hline \multicolumn{11}{|c|}{ Desmedipham } \\
\hline 318 & {$\left[\mathrm{M}+\mathrm{H}+\mathrm{NH}_{3}\right]^{+}$} & 15 & 28 & 13 & 10 & 15 & 12 & 21 & 30 & 2 \\
\hline 213 & $?$ & 9 & 10 & - & 10 & 13 & - & 12 & 40 & 8 \\
\hline 199 & {$\left[\mathrm{M}+\mathrm{H}+\mathrm{NH}_{3}-\mathrm{C}_{6} \mathrm{H}_{5} \mathrm{NCO}^{+}\right.$} & 100 & 100 & 100 & 100 & 100 & 99 & 100 & 100 & 9 \\
\hline 196 & $?$ & 10 & - & 45 & 12 & - & 38 & 10 & - & 5 \\
\hline 182 & {$\left[\mathrm{M}+\mathrm{H}-\mathrm{C}_{6} \mathrm{H}_{5} \mathrm{NCO}\right]^{+}$} & 13 & 14 & 19 & 22 & 19 & 87 & 38 & 70 & 57 \\
\hline 169 & $\begin{array}{l}{\left[\mathrm{C}_{6} \mathrm{H}_{5} \mathrm{NCO}+\mathrm{H}+\mathrm{NH}_{3}\right.} \\
\left.+\mathrm{CH}_{3} \mathrm{OH}\right]^{+}\end{array}$ & 23 & 6 & 9 & 37 & 10 & 8 & 63 & 15 & 1 \\
\hline 154 & {$\left[\mathrm{C}_{6} \mathrm{H}_{5} \mathrm{NCO}+\mathrm{H}+\left(\mathrm{NH}_{3}\right)_{2}\right]^{+}$} & 9 & - & 11 & 9 & - & 7 & 6 & - & - \\
\hline 152 & {$\left[\mathrm{C}_{6} \mathrm{H}_{5} \mathrm{NCO}+\mathrm{H}+\mathrm{CH}_{3} \mathrm{OH}\right]^{+}$} & - & - & - & - & - & 2 & 9 & - & 2 \\
\hline 137 & {$\left[\mathrm{C}_{6} \mathrm{H}_{5} \mathrm{NCO}+\mathrm{H}+\mathrm{NH}_{3}\right]^{+}$} & - & 5 & 31 & - & 10 & 100 & 32 & 50 & 100 \\
\hline \multicolumn{11}{|l|}{ Isoprocarb } \\
\hline 252 & {$[M+59]^{+}$} & 2 & 9 & 6 & - & 5 & 4 & - & - & - \\
\hline 211 & {$\left[\mathrm{M}+\mathrm{H}+\mathrm{NH}_{3}\right]^{+}$} & 100 & 100 & 100 & 100 & 100 & 100 & 100 & 100 & 41 \\
\hline 194 & {$[\mathrm{M}+\mathrm{H}]^{+}$} & 13 & 9 & 9 & 14 & 12 & 44 & 23 & 48 & 100 \\
\hline
\end{tabular}


Table 3. Main ions ( $m / z$ and relative abundances) and mass assignment of the investigated carbamates by filament-assisted buffer ionization. Comparison of three commercial TSP systems (A, B, and C) at source temperatures 200,250 , and $\left.300^{\circ} \mathrm{C}\right)^{\mathrm{a}}($ continued $)$

\begin{tabular}{|c|c|c|c|c|c|c|c|c|c|c|}
\hline \multirow[b]{2}{*}{$m / z$} & \multirow[b]{2}{*}{ Structure } & \multicolumn{3}{|c|}{$200^{\circ} \mathrm{C}$} & \multicolumn{3}{|c|}{$250^{\circ} \mathrm{C}$} & \multicolumn{3}{|c|}{$300^{\circ} \mathrm{C}$} \\
\hline & & A & B & $\mathrm{C}$ & $\mathrm{A}$ & B & $\mathrm{C}$ & $\mathrm{A}$ & $B$ & $\mathrm{C}$ \\
\hline \multicolumn{11}{|c|}{ Methomyl } \\
\hline 342 & {$\left[\mathrm{M}_{2} \mathrm{H}+\mathrm{NH}_{3}\right]^{+}$} & 5 & 15 & - & 1 & - & - & 1 & - & - \\
\hline 325 & {$\left[\mathrm{M}_{2} \mathrm{H}\right]^{+}$} & 8 & 8 & - & 2 & - & - & 1 & - & - \\
\hline 221 & {$[M+59]^{+}$} & 4 & 19 & 10 & 5 & 12 & 11 & 1 & - & - \\
\hline 194 & {$[M+32]^{+}$} & 23 & 5 & 2 & 15 & 1 & - & 7 & - & - \\
\hline 180 & {$\left[\mathrm{M}+\mathrm{H}+\mathrm{NH}_{3}\right]^{+}$} & 72 & 100 & 14 & 32 & 39 & 2 & 10 & 5 & - \\
\hline 163 & {$[\mathrm{M}+\mathrm{H}]^{+}$} & 100 & 65 & 100 & 100 & 100 & 100 & 100 & 100 & 100 \\
\hline \multicolumn{11}{|l|}{ Oxamyl } \\
\hline 278 & {$[M+59]^{+}$} & 2 & 11 & 12 & - & 12 & 8 & - & - & 27 \\
\hline 251 & {$[M+32]^{+}$} & 10 & 5 & 2 & 5 & 3 & - & 2 & - & - \\
\hline 237 & {$\left[\mathrm{M}+\mathrm{H}+\mathrm{NH}_{3}\right]^{+}$} & 100 & 100 & 100 & 100 & 100 & 62 & 100 & 19 & 59 \\
\hline 221 & {$\left[\mathrm{M}-\mathrm{CH}_{3} \mathrm{NCO}+59\right]^{+}$} & 3 & 12 & 3 & 6 & 6 & - & 3 & - & - \\
\hline 195 & {$\left[\mathrm{M}+\mathrm{CH}_{3} \mathrm{OH}-\mathrm{CH}_{3} \mathrm{NCO}\right]^{+}$} & 5 & 12 & - & 1 & 6 & - & - & - & - \\
\hline 180 & {$\left[\mathrm{M}+\mathrm{H}+\mathrm{NH}_{3}-\mathrm{CH}_{3} \mathrm{NCO}^{+}\right.$} & 20 & 84 & 11 & 9 & 38 & 3 & 2 & 7 & - \\
\hline 163 & {$\left[\mathrm{M}+\mathrm{H}-\mathrm{CH}_{3} \mathrm{NCO}\right]^{+}$} & 19 & 52 & 54 & 20 & 88 & 100 & 15 & 100 & 100 \\
\hline \multicolumn{11}{|c|}{ Phenmedipham } \\
\hline 318 & {$\left[\mathrm{M}+\mathrm{H}+\mathrm{NH}_{3}\right]^{+}$} & 23 & 34 & 14 & 12 & 36 & 10 & 20 & na & 4 \\
\hline 241 & {$\left[\mathrm{M}+\mathrm{H}-\mathrm{CH}_{3} \mathrm{CO}_{2} \mathrm{H}\right]^{+}$} & - & 8 & - & - & 16 & - & - & na & - \\
\hline 210 & $?$ & 20 & 7 & 35 & 13 & 9 & 23 & 13 & na & 4 \\
\hline 185 & {$\left[\mathrm{M}+\mathrm{H}+\mathrm{NH}_{3}-{\text { isocyanate }]^{+}}^{+}\right.$} & 100 & 100 & 100 & 100 & 100 & 84 & 100 & na & 21 \\
\hline 183 & [isocyanate $\left.+\mathrm{CH}_{3} \mathrm{OH}+\mathrm{NH}_{4}\right]^{4}$ & 21 & - & 8 & 20 & - & 6 & 20 & na & 3 \\
\hline 168 & {$\left[\mathrm{M}+\mathrm{H}-{\text { isocyanate }]^{+}}^{+}\right.$} & 22 & 13 & 16 & 22 & 16 & 34 & 25 & na & 38 \\
\hline 151 & [isocyanate $\left.+\mathrm{H}+\mathrm{NH}_{3}\right]^{+}$ & 11 & 5 & 38 & 18 & 14 & 100 & 40 & na & 100 \\
\hline \multicolumn{11}{|c|}{ Promecarb } \\
\hline 266 & {$[M+59]^{+}$} & 2 & 12 & - & 1 & 7 & - & 1 & 8 & 2 \\
\hline 225 & {$\left[\mathrm{M}+\mathrm{H}+\mathrm{NH}_{3}\right]^{+}$} & 100 & 100 & 100 & 100 & 100 & 100 & 100 & 100 & 22 \\
\hline 208 & {$[\mathrm{M}+\mathrm{H}]^{+}$} & 15 & 10 & - & 20 & 17 & - & 40 & 75 & 100 \\
\hline \multicolumn{11}{|l|}{ Propoxur } \\
\hline 268 & {$[M+59]^{+}$} & 3 & 10 & 18 & 2 & 8 & 5 & 1 & 5 & - \\
\hline 227 & {$\left[\mathrm{M}+\mathrm{H}+\mathrm{NH}_{3}\right]^{+}$} & 100 & 100 & 91 & 100 & 100 & 17 & 63 & 35 & 2 \\
\hline 210 & {$[\mathrm{M}+\mathrm{H}]^{+}$} & 32 & 21 & 100 & 60 & 65 & 100 & 100 & 100 & 100 \\
\hline 168 & {$\left[\mathrm{M}+\mathrm{H}-\mathrm{C}_{3} \mathrm{H}_{6}\right]^{+}$} & 1 & - & - & 1 & - & - & 1 & 7 & 4 \\
\hline \multicolumn{11}{|c|}{ Thiodicarb } \\
\hline 372 & {$\left[\mathrm{M}+\mathrm{H}+\mathrm{NH}_{3}\right]^{+}$} & 44 & 57 & 10 & 6 & 31 & - & 3 & 4 & - \\
\hline 355 & {$[\mathrm{M}+\mathrm{H}]^{+}$} & 82 & 31 & 100 & 40 & 88 & 100 & 62 & 55 & 83 \\
\hline 224 & {$\left[\mathrm{M}+\mathrm{H}-\mathrm{CH}_{3} \mathrm{SC}\left(\mathrm{CH}_{3}\right) \mathrm{NOCO}_{2} \mathrm{H}\right]^{+}$} & 100 & 100 & 36 & 62 & 73 & - & 65 & 20 & - \\
\hline \multirow[t]{2}{*}{194} & {$\left[\mathrm{CH}_{3} \mathrm{NHCO}_{2} \mathrm{~N}=\mathrm{C}\right.$} & 10 & 4 & - & 10 & 4 & - & 1 & 2 & - \\
\hline & $\left.\left(\mathrm{CH}_{3}\right) \mathrm{SCH}_{3}+\mathrm{CH}_{3} \mathrm{NH}_{3}\right]^{+}$ & & & & & & & & & \\
\hline \multirow[t]{2}{*}{180} & {$\left[\mathrm{CH}_{3} \mathrm{NHCO}_{2} \mathrm{~N}=\mathrm{C}\right.$} & 31 & 86 & 7 & 20 & 41 & 1 & 6 & 5 & - \\
\hline & $\left.\left(\mathrm{CH}_{3}\right) \mathrm{SCH}_{3}+\mathrm{H}+\mathrm{NH}_{3}\right]^{+}$ & & & & & & & & & \\
\hline \multirow[t]{2}{*}{163} & {$\left[\mathrm{CH}_{3} \mathrm{NHCO}_{2} \mathrm{~N}=\mathrm{C}\right.$} & 51 & 35 & 48 & 100 & 100 & 85 & 100 & 100 & 100 \\
\hline & $\left.\left(\mathrm{CH}_{3}\right) \mathrm{SCH}_{3}+\mathrm{H}\right]^{+}$ & & & & & & & & & \\
\hline \multicolumn{11}{|c|}{ Thiofanox } \\
\hline 277 & {$[M+59]^{+}$} & 10 & 23 & 29 & 5 & 100 & 28 & 1 & 37 & 35 \\
\hline 250 & {$[M+32]^{+}$} & 48 & 4 & - & 60 & 9 & - & 45 & 10 & - \\
\hline 236 & {$\left[\mathrm{M}+\mathrm{H}+\mathrm{NH}_{3}\right]^{+}$} & 100 & 100 & 13 & 45 & 44 & - & 5 & 8 & - \\
\hline 219 & {$[\mathrm{M}+\mathrm{H}]^{+}$} & 80 & 64 & 34 & 65 & 66 & 6 & 23 & 25 & - \\
\hline 162 & {$\left[\mathrm{M}+\mathrm{H}-\mathrm{CH}_{3} \mathrm{NCO}^{+}\right.$} & 5 & 4 & 12 & 7 & 8 & 26 & 10 & 40 & 88 \\
\hline 146 & $?$ & 32 & - & 7 & 100 & - & 10 & 100 & - & 10 \\
\hline 144 & {$\left[\mathrm{M}+\mathrm{H}-\mathrm{CH}_{3} \mathrm{NHCO}_{2} \mathrm{H}^{+}\right.$} & 45 & 20 & 100 & 77 & 55 & 100 & 96 & 100 & 100 \\
\hline
\end{tabular}

${ }^{a}$ Mobile phase composition: $50-\mathrm{mM}$ ammonium acetate in methanol: water $50: 50(\mathrm{v} / \mathrm{v}) ; 1.0 \mathrm{~mL} / \mathrm{min}$. na $=$ not acquired 
Table 4. $[\mathrm{M}+\mathrm{H}]^{+} /\left[\mathrm{M}+\mathrm{H}+\mathrm{NH}_{3}\right]^{+}$relative abundance ratios in the thermospray mass spectra of promecarb obtained with a triple-stage quadrupole system by using either $\mathrm{Q} 1$ or $\mathrm{Q} 3$ as the scanning device at ion source temperatures of 200,250, and $300^{\circ} \mathrm{C}$

\begin{tabular}{cccc}
\hline Quad & $200^{\circ} \mathrm{C}$ & $250^{\circ} \mathrm{C}$ & $300^{\circ} \mathrm{C}$ \\
\hline \hline 01 & 0.11 & 0.56 & 2.85 \\
Q3 & 0.33 & 1.08 & 3.97
\end{tabular}

Systems A and B can generate a higher pressure in this region, which makes adduct ion formation more favorable. This explanation is consistent with the observation that adduct ion formation is more abundant in these systems.

In all three interfaces, increased ion source temperature decreased the relative abundance of ammonium adduct ions. This effect has been reported before [5] and was due to dissociative processes. These processes also can explain the increase of the fragment ion abundance of the $\left[\mathrm{M}+\mathrm{H}-\mathrm{CH}_{3} \mathrm{NCO}^{+}\right.$and $[\mathrm{M}+\mathrm{H}-$ $\left.\mathrm{CH}_{3} \mathrm{NHCOOH}\right]^{+}$ions with increased ion source temperature, especially for the oxime $N$-methylcarbamates, the $N$-phenylcarbamates, the methyl ester substituted carbamic acids, and the aryl $N$-methylcarbamate aminocarb. The presence of thermally assisted hydrolysis of the carbamate group also should be considered. Other aryl $\mathrm{N}$-methylcarbamates do not show a significant increase in fragmentation when the ion source temperature is increased.

Most interesting was the fact that an increase in the source temperature by $50^{\circ} \mathrm{C}$ allowed a much larger effect on the mass spectrum of a particular compound to be observed with System $C$ than by application of the same temperature raise with the two other interfaces. These experimental results can be explained readily by the fact that the reagent ion pressures are probably higher in Systems A and B in comparison to source $C$, and thus a collision stabilization of the quasimolecular ions take place, even at higher source temperatures.

\section{Solvent-Mediated Chemical Ionization}

The mass spectra in the solvent-mediated $\mathrm{Cl}$ mode were in general consistent with those obtained in the filament-assisted buffer ionization mode, although in the solvent-mediated CI mode a somewhat higher fragmentation level is observed $[1,6]$ due to the lower proton affinity of the organic modifiers (methanol or acetonirril) as compared to ammonia. In addition, in several solvent-mediated $\mathrm{CI}$ experiments mass spectra

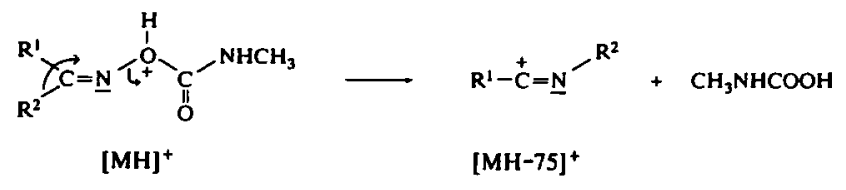

Scheme I. were observed with abundant sodium and potassium adduct ions with System C. These adduct ions probably were due to impurities in the mobile phase. The presence of these types of ions in TSP has been reported previously [26]. Figure 2 summarizes the solvent-mediated CI mass spectra of aminocarb for Sys-
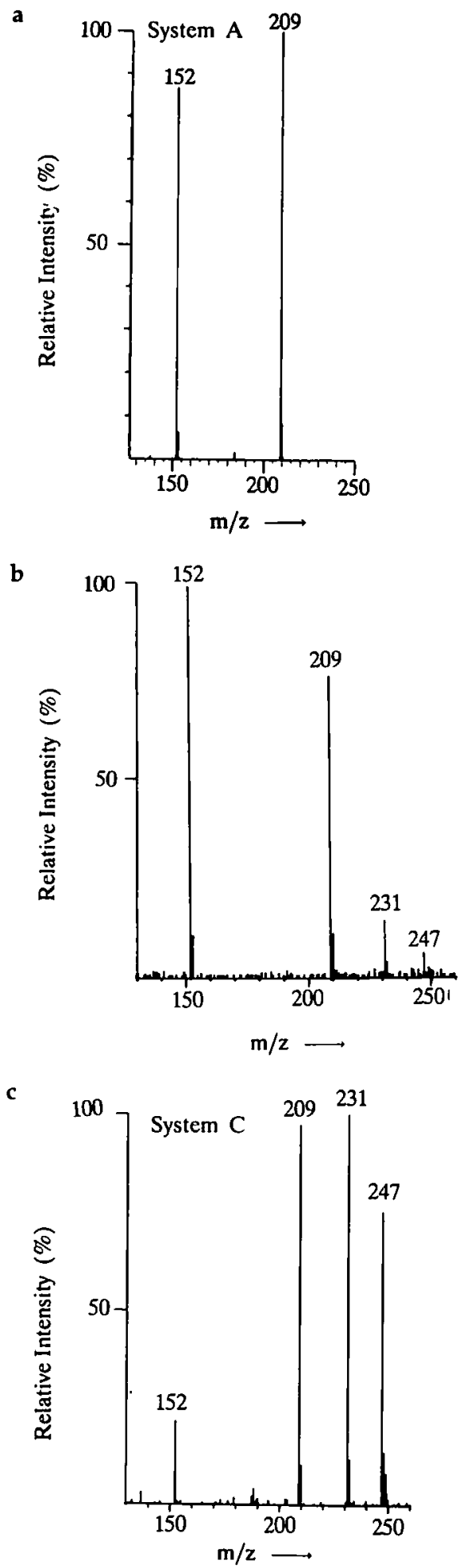

Figure 2. Solvent-mediated $C I$ spectra of aminocarb obtained with (a) System A, (b) System B, and (c) System C (ion source temperature, $250^{\circ} \mathrm{C}$ ). 
tems $\mathrm{A}, \mathrm{B}$, and $\mathrm{C}$. The relative abundance of the fragment ion $\left[\mathrm{M}+\mathrm{H}-\mathrm{CH}_{3} \mathrm{NCO}\right]^{+}$at $\mathrm{m} / z 152$ was lower in the mass spectra obtained with System $\mathrm{C}$ than with the other systems. This behavior is consistent with the alkali metal ion adduct formation mentioned in the preceding text. $[\mathrm{M}+\mathrm{Na}]^{+}$and $[\mathrm{M}+\mathrm{K}]^{+}$ions are more stable than the corresponding protonated molecule ion or molecular ammonium adduct ions and thus lead to a decrease in fragmentation. The same effect also has been observed with the pneumatically assisted electrospray interface (Honing, M.; Riv, J.; Barceló, D.; van Baar, B. L. M.; Brinkman, V. A. Th. unpublished).

By increasing the ion source temperature, large increases were not detected in the thermally assisted hydrolysis formation of the methylisocyanate from the carbamate moiety as observed in the filament-assisted buffer ionization mode. This result can be explained by the fact that differences in temperature of the vaporizer and ion source were not as important in this mode because of the higher degree of fragmentation already present caused by the lower proton affinities of the reagent ions.

\section{The $[M+32]+$ Ion}

For oxime $\mathrm{N}$-methylcarbamates $[\mathrm{M}+32]^{+}$and/or $[\mathrm{M}+59]^{+}$adduct ions were observed similar to other reports [8, 19]. Saar and Salomon [18] suggested a multistep fragmentation reaction that involves radical species to form the corresponding reagent ions. However, the formation of protonated methylamine $(\mathrm{m} / \mathrm{z}$ 32) more likely is due to thermally assisted hydrolysis in the vaporizer probe of the neutral precursor molecules prior to ionization followed by gas phase ionization to form the $[\mathrm{M}+32]^{+}$ion (see following text). The origin of the $[\mathrm{M}+59]^{+}$ion (an impurity of the commercially available ammonium acetate) has been reported by us [27].

The $[\mathrm{M}+32]^{+}$adduct ions were most abundant with System A, whereas System C exhibited [M+32] ${ }^{+}$ ions only with low relative abundances. For System B an intermediate abundance was found (Table 3). With aryl $\mathrm{N}$-methylcarbamates no $[\mathrm{M}+32]^{+}$ions were observed, which readily can be explained by their greater thermal stability.

Methylisocyanate $\left(\mathrm{CH}_{3} \mathrm{NCO}\right)$ and eventually methylamine $\left(\mathrm{CH}_{3} \mathrm{NH}_{2}\right)$ can be formed from the carbamate pesticides by thermally assisted hydrolysis in the vaporizer [23]. The proton affinity of methylamine is high $(896 \mathrm{~kJ} /$ mole [24]). Protonated methylamine at $\mathrm{m} / \mathrm{z} 32$ readily forms adduct ions with the neutral carbamates in the gas phase. This hypothesis was supported by experiments in which the $[\mathrm{M}+32]^{+}$ion of aldicarb was monitored as a function of the vaporizer temperature, as illustrated in Figure 3. By raising the vaporizer temperature, a strong increase in the $[\mathrm{M}+32]^{+}$ion abundance was observed. Further confirmation was achieved by low energy tandem mass spectrometry

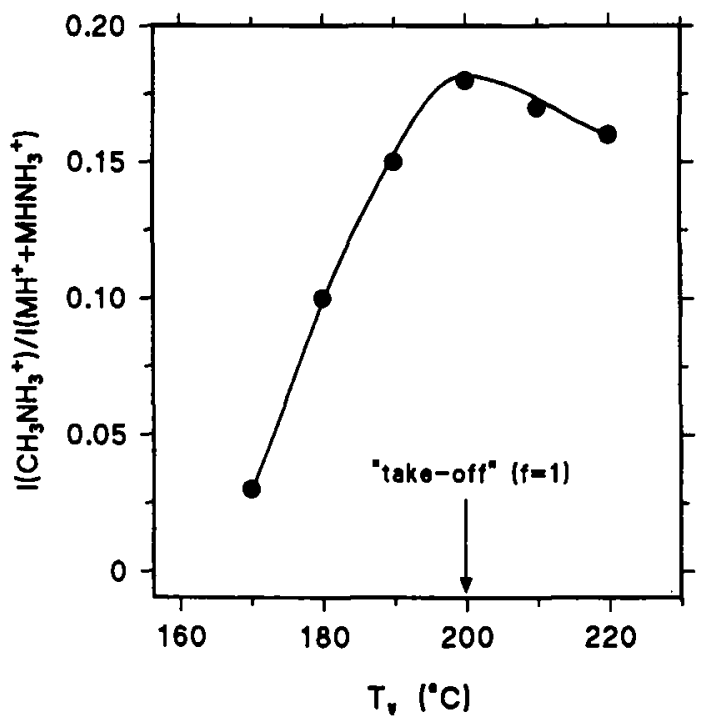

Figure 3. Relative intensity of the $[M+32]^{+}$reagent ion formed by thermally assisted hydrolysis of the parent compound aldicarb as a function of the vaporizer temperature (System A).

experiments with the $[\mathrm{M}+32]^{+}$ion. The collisionactivated dissociation spectrum of these ions exhibited $[\mathrm{MH}]^{+}$ions and an ion at $m / z 32$.

In contrast to the molecular ammonium adduct ions, the relative abundances of the $[M+32]^{+}$adduct ions of aldicarb and butocarboxim increased when the ion source temperature was increased by $100^{\circ} \mathrm{C}$ (Table 3 ). A possible explanation involves consideration of thermal dissociations of the $N$-methylcarbamate group in the ion source. However, the abundance of the [M+ $32]^{+}$ions for methomyl and oxamyl decreased with increasing ion source temperature.

In summary the formation of $[\mathrm{M}+32]^{+}$ions mainly depends on the design of the vaporizer probe rather than the ion source geometry. Differences in the relative abundances of this ion between the three investigated ion sources probably do not reflect differences in the source designs.

\section{$S / N$ Ratio}

The influence of the ion source temperature on the signal-to-noise $(\mathrm{S} / \mathrm{N})$ ratios of the protonated molecules of methomyl, promecarb, and thiodicarb was investigated with the three systems.

The results are summarized in Figure $4 a-c$, where the signal-to-noise ratios are plotted as a function of the ion source temperature. All $\mathrm{S} / \mathrm{N}$ ratio curves maximize within a narrow temperature range of approximately $250-260^{\circ} \mathrm{C}$. The initial increase of these curves was believed to be due to stabilization of the aerosol and a more complete desolvation of the droplets [5]. This enhanced desolvation eventually increased the number of neutral molecules in the gas phase prior to ionization and/or favored the enhanced formation of completely desolvated ions in the mobile phase. 
a

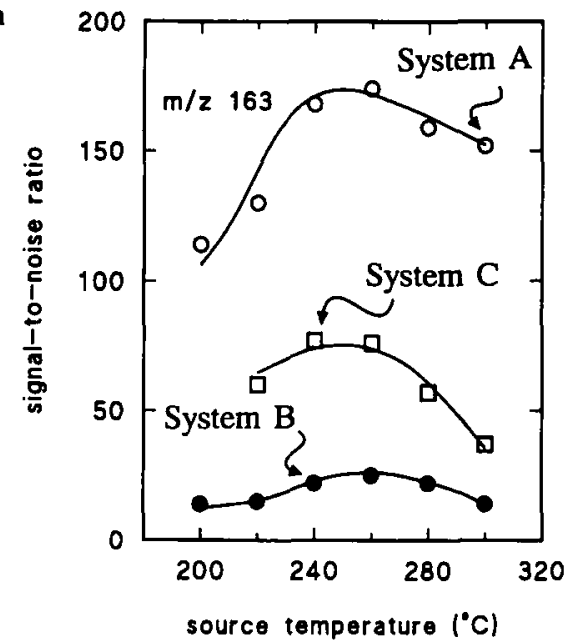

b
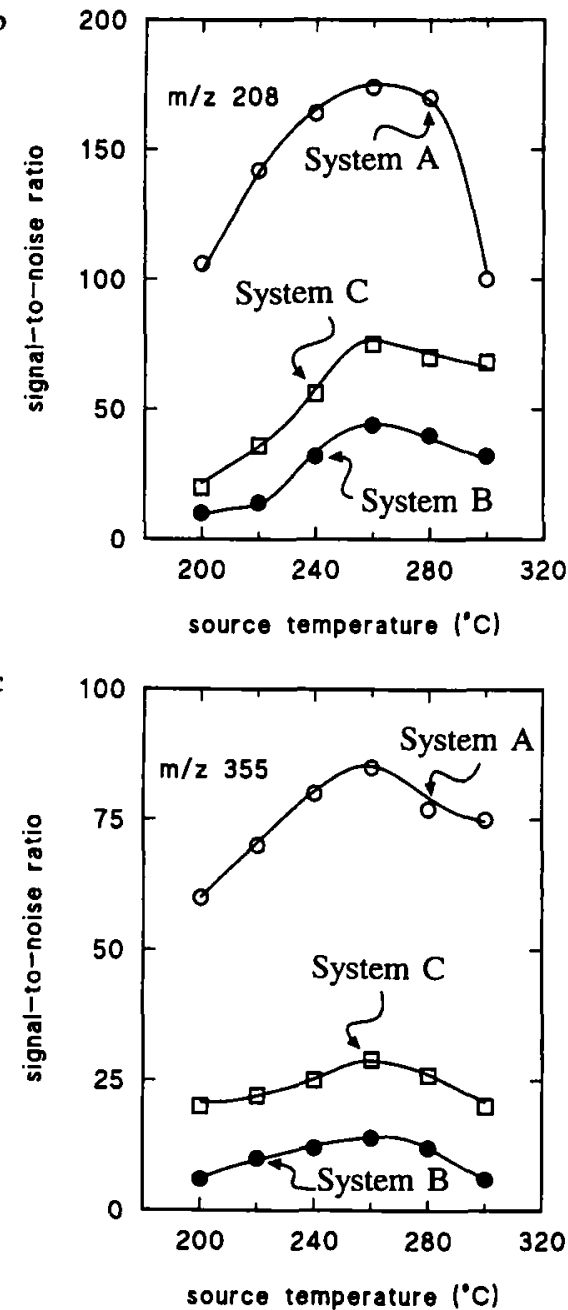

Figure 4. Signal-to-noise ratios for the $[M+H]^{+}$ions of (a) methomyl $(m / z$ 163), (b) promecarb $(m / z 208)$, and (c) thiodicarb $(m / z 355)$ as a function of the ion source temperature with Systems A, B, and C.

Decrease of the $S / N$ ratio curves for temperatures $>260^{\circ} \mathrm{C}$ in the case of methomyl and promecarb was due to thermally assisted fragmentation and/or the instability of the spray. The latter effect has been reported for the direct liquid introduction interface
[28]. For thiodicarb, no significant changes of the absolute $[\mathrm{M}+\mathrm{H}]^{+}$ion currents were observed for ion source temperatures higher than $260^{\circ} \mathrm{C}$. Thus the initial increase in $\mathrm{S} / \mathrm{N}$ was caused by an increase in signal intensities of the $[\mathrm{M}+\mathrm{H}]^{+}$ions, whereas the decrease above $\sim 260^{\circ} \mathrm{C}$ mainly was due to an increase in noise. In the case of methomyl and promecarb, both increased noise and decreased absolute signal intensities were responsible for the curve shape at higher temperatures.

\section{Conclusion}

The results of this study, using three different thermospray interfaces, have demonstrated via standardization of the experimental parameters, that for 12 of the investigated compounds no significant differences in the mass spectra were observed, especially for low ion source temperatures. Therefore, it can be stated that for sufficiently thermally stable molecules the ion source geometry has only a small influence on the actual ion formation. Significant differences in mass spectra between the three interfaces at a given temperature were observed for the thermally labile compounds asulam, thiodicarb, and thiofanox. These differences mainly were due to thermally assisted hydrolysis of the parent compounds in the vaporizer probe and thus do not necessarily reflect differences in the ion source geometry. Standardization of the vaporizer conditions was difficult and therefore differences with thermally labile compounds may occur. The presence of $[M+32]^{+}$ions in the mass spectra of oxime $\mathrm{N}$-methylcarbamates was consistent with this explanation.

Differences were observed in the mass spectra of carbofuran for low source temperatures. These differences were caused by changes in the relative intensities of the molecular ammonium adduct ion and the protonated molecule ion with temperature and reagent ion pressure, and thus directly reflect differences in source geometry. These effects were more pronounced with a larger ionization chamber and a lower reagent ion pressure in the source. An increase of the pressure due to a narrowing of the desolvation and ionization chamber can cause collision stabilization of both the molecular ammonium adduct ion and the protonated molecule ion.

At higher ion source temperatures, loss of ammonia from the molecular ammonium adduct ions and thermal fragmentations can take place in all three interfaces. The extent of this dissociation depends on the interface type, and consequently the mass spectra observed for higher source temperatures were less consistent. By taking into account the strong dependence of the $S / N$ ratios on the ion source temperature, $250-260^{\circ} \mathrm{C}$ is considered to be optimal with respect to sensitivity and spectral compatibility for all three interfaces.

Mass spectral differences between the various inter- 
face types for all investigated compounds were mainly due to temperature and related pressure effects. Differences in source geometry were considered only to promote these spectral differences because of their effect on the ion source pressure.

\section{Acknowledgments}

$M$. $H$. has a fellowship from the Spanish government (contract SB94-AE0569794). D. V. and K. L. acknowledge financial support from the German Federal Department of Research and Technology (BMFT, Bonn, Germany). Maria E. Jager (Department of Analytical Chemistry, Free University, Amsterdam, The Netherlands) is thanked for her assistance with the TSP experiments. The authors thank Dr. Thomas Cairns (USFDA /ORA, Los Angeles, CA) for helpful discussions. This research was supported by the Environmental Programme of the Commission of the European Communities (contract EV5V-T92-0061) and CICYT (contract AMB95-1230-CE).

\section{References}

1. Honing, M.; Barceló, D.; van Baar, B. L. M.; Ghijsen, R. T.; Brinkman, U. A. Th. J. Am. Soc. Mass Spectrom. 1994, 5 , 913-927.

2. Durand, G.; de Bertrand, N.; Barceló, D. /. Chromatogr. 1991, 562, 507-523.

3. Barceló, D.; Durand, G.; Vreeken, R. J.; de Jong, G. J.; Lingeman, H. L.; Brinkman, U. A. Th. I. Chromatogr. 1991, 553, 311-328.

4. Volmer, D.; Levsen, K. J. Am. Soc. Mass Spectrom. 1994, 5, 655-676.

5. Volmer, D.; Levsen, K.; Wünsch, G. J. Chromatogr. 1993, 647, 235-259.

6. Volmer, D.; Levsen, K.; Wünsch, G. J. Chromatogr. A 1994, $660,231-248$.

7. Volmer, D.; Levsen, K., Engewald, W. Vom Wasser 1994, 82, 335-364.
8. Voyksner, R. D. Anal. Chem. 1985, 57, 2600-2605.

9. Covey, T. R.; Crowther, J. B.; Dewey, E. A.; Henion, J. D. Anal. Chem. 1985, 57, 474-481.

10. Kostiainen, R. J. Chromatogr. 1991, 562, 555-562.

11. Rajakyla, E.; Laasasenaho, K.; Sakkers P. J. D. J. Chromatogr. 1987, 384, 391-402.

12. Lopez-Avila, V.; Jones, T. L. J. Assoc. Off. Anal. Chem. 1993, $76,1329-1343$.

13. Jones, T. L.; Betowski, L. D.; Lopez-Avila, V. Trends Anal. Chem. 1994, 13, 333-338.

14. Lindberg, C.; Paulson, J. J. Chromatogr. 1987, 394, 117-122.

15. McFadden, W. H.; Lammert, S. A. I. Chromatogr. 1987, 385, 201-211.

16. Liberato, D. J.; Yergey, A. L. Anal. Chem. 1986, 56, 6-9.

17. Nehring, H.; Thiebes, S.; Butfering, L.; Röllgen, F. W. Int. J. Mass Spectrom. Ion Processes 1993, 128, 123-132.

18. Saar, A.; Salomon, A. Org. Mass Spectrom. 1990, 25, 209-213.

19. Vreeken, R. J.; van Dongen, W. D.; Ghijsen, R. T.; Brinkman, U. A. Th. Int. /. Environ. Anal. Chem. 1994, 54, 119-145.

20. Pleasance, S.; Anacleto, J. F.; Bailey, M. R.; North, D. H. J. Am. Soc. Mass Spectrom. 1992, 3, 378-397.

21. Lynn, B. C., Jr.; Marbury, G. D.; Tuschall, J. R., Jr. Org. Mass Spectrom. 1988, 23, 736-738.

22. Cairns, T.; Siegmund, E. G.; Stamp, J. J. Biomed. Mass Spectrom. 1984, 11, 301-307.

23. Chiron, S.; Dupas, S.; Scribe, P.; Barceló, D. J. I. Chromatogr. 1994, 665, 295-305.

24. Durand, G.; De Bertrand, N.; Barceló, D. J. Chromatogr. 1991, $562,507-523$.

25. Chiu, K. S.; van Langenhove, A.; Tanaka, C. Biomed. Environ. Mass Spectrom. 1989, 18, 200-206.

26. Voyksner, R. D.; Bursey, J. T.; Pellizzari, E. D. Anal. Chem. 1984, 56, 1507-1514.

27. Abián, J.; Sánchez-Baeza, F.; Gelpí, E.; Barceló, D. J. Am. Soc. Mass Spectrom. 1994, 5, 186-194.

28. Voyksner, R. D. Org. Mass Spectrom. 1987, 22, 513-518. 